\title{
Fatty acid composition of Piedmont "Ossolano" cheese
}

\author{
Giuseppe ZEPPA ${ }^{\mathrm{a} *}$, Manuela GIORDANO ${ }^{\mathrm{a}}$, Vincenzo GERBI ${ }^{\mathrm{a}}$, Marco ARLORIO ${ }^{\mathrm{b}}$ \\ ${ }^{\text {a }}$ Dipartimento di valorizzazione e protezione delle risorse agroforestali, Università degli Studi di Torino, \\ Via L. da Vinci 44, 10095 Grugliasco (TO), Italy \\ ${ }^{\mathrm{b}}$ Dipartimento di scienze chimiche, alimentari, farmaceutiche, farmacologiche, Università del Piemonte \\ Orientale, Viale Ferrucci 33, 28100 Novara, Italy
}

(Received 19 March 2002; accepted 13 November 2002)

\begin{abstract}
Fatty acid composition of 66 samples of "Ossolano", a typical semi-hard cheese produced from raw cow milk in the Ossola valley (North Piedmont, West Italy) was determined. The survey was carried out on 24 summer cheeses produced in mountain farms (1500-2200 m) with milk from pasture-fed cows and 42 winter cheeses produced in valley farms $(500-800 \mathrm{~m})$ with milk from hay- and concentrate-fed cows. Seasonal variation in feeding condition was responsible for the observed variations in fatty acid composition of the samples. Long-chain mono- and polyunsaturated fatty acids were more abundant in the summer cheeses while short- and medium-chain saturated fatty acids were higher in winter products. The ratio of saturated to unsaturated fatty acids was thus lower in summer cheeses compared with winter cheeses. Conjugated linoleic acids, $n-3$ and n- 6 acids were instead higher in summer cheeses according to the results of many authors. The $\mathrm{n}-6 / \mathrm{n}-3$ ratio is lower in the summer products with an interesting nutritional effect due to the essential role of n-3 polyunsaturated fatty acid in human health.
\end{abstract}

Fatty acid / mountain cheese / Ossolano cheese / conjugated linoleic acid

Résumé - Composition en acides gras du fromage « Ossolano » du Piémont. La composition en acides gras a été déterminée dans 66 échantillons d' " Ossolano », un fromage à pâte semi-dure qui est produit à partir du lait cru dans la vallée de l'Ossola (Piémont du Nord, Italie). Vingt-quatre de ces fromages ont été fabriqués en été à partir de laits produits sur des pâturages de montagne (1500$2200 \mathrm{~m}$ ) et quarante-deux en hiver à partir de laits produits dans la vallée (500-800 m) avec une alimentation à base de foin et de céréales. Le changement dans l'alimentation a déterminé le changement de la composition en acides gras des fromages. La proportion en acides gras à chaîne longue mono- et poly-insaturés était significativement plus élevée dans les fromages d'été, alors que celle des acides gras saturés à chaîne courte et moyenne était plus élevée dans les fromages d'hiver. Par conséquent le rapport entre les acides saturés et acides insaturés était plus petit dans les fromages d'été que dans les fromages d'hiver. Les CLA et les acides n-3 et n-6 sont plus élevés dans les fromages produits en été comme de nombreux auteurs l'ont déjà souligné. Le rapport n-6/n-3 est plus petit pour les fromages produits en été, ce qui entraîne un effet nutritionnel intéressant grâce au rôle essentiel des acides gras poly-insaturés n-3 dans l'alimentation humaine.

\section{Acide gras / fromage de montagne / fromage « Ossolano » / acide linoléique conjugué}

* Correspondence and reprints

Tel.: (39) 011 6708550; fax: (39) 011 6708549; e-mail: giuseppe.zeppa@unito.it 


\section{INTRODUCTION}

Lipids are very important components of the human diet for their indispensable vital functions. Modern guidelines for a healthy diet recommend, however, reducing animal fat consumption, especially if rich in saturated fatty acids, due to their by now well-demonstrated hypercholesterolemic effect. But it is important to remember that there are also unsaturated fatty acids present in animal fat which may not only reduce the cholesterol content in the blood, but in some cases even have anticarcinogenic effects and develop a protection to cardiovascular diseases [1, 12, 14, 25, 28]. Linoleic $\left(C_{18: 2} n-6\right)$ and linolenic $\left(C_{18: 3}\right.$ n-3) acids are even known as "indispensable fatty acids" which cannot be synthesized by men or animals.

Fatty acids of milk are derived from two major sources. Acetate and 3-OH-butyrate originating from ruminal fermentation are the carbon sources for $\mathrm{C}_{4: 0}$ to $\mathrm{C}_{14: 0}$ and one half of $\mathrm{C}_{16: 0}$ fatty acids. The remaining $\mathrm{C}_{16: 0}$ and all of the longer-chain fatty acids are derived from blood lipids produced during the digestion and absorption of dietary fat or from mobilization of fatty acids from adipose tissue [10, 18, 34]. So diet could modify the chemical composition of milk and thus influence the composition of milk products $[2,5,6,8,9,11,19,27,31]$. Recent studies have shown that pasturing or feeding cows with green forage determines an increase in the unsaturated longchain fatty acids and a reduction in the short-chain saturated ones $[2,7,13,15,20$, $33,35]$. This effect is particularly evident in the traditional mountain cheeses due to prolonged grazing on a variety of vegetal essences even though not many studies on these particular products have yet been done $[3,4,6]$. The aim of this work was to verify if for "Ossolano" cheese, one of the best-known Piedmont cheeses, it was also possible to observe a fatty acid difference between the summer production (cows fed with green forage in mountain pasture) and the winter production (cows fed with hay and concentrate in valley farms).

\section{MATERIALS AND METHODS}

\subsection{Samples}

"Ossolano" cheese is a round semi-hard cheese weighing 8-9 kg and made using raw milk exclusively from Bruna Alpina cows. This cheese is produced in the north of Piedmont, in the alpine zone bordering Switzerland. For the cheesemaking, raw whole (in summer) or raw partially skimmed (in winter) cow milk is coagulated without starter at $34-37{ }^{\circ} \mathrm{C}$ by adding bovine rennet. The curd is cut with a wire cutter into 3-4 mm curd particles. The curd-whey mixture is heated to $37-45^{\circ} \mathrm{C}$ over a period of 15-48 min and then stirred without heating for a further $40 \mathrm{~min}$. The curd is finally removed and placed into moulds, drained and pressed for $24 \mathrm{~h}$. The cheeses are then removed from the moulds and salted dry for $48 \mathrm{~h}$ after which they are ripened at $8-12{ }^{\circ} \mathrm{C}$ in curing rooms at high humidity (80-90\%).

The survey was carried out on 66 cheese samples, of which 24 were from the summer production of mountain farms located between $1500 \mathrm{~m}$ and $2200 \mathrm{~m}$ (S: 7 producers) and 42 from the winter production of valley farms (W: 6 producers). Summer feeding was exclusively green forage in mountain pastures whereas hay and concentrate were used for winter feeding.

Each sample was collected from a whole cheese after $60 \mathrm{~d}$ of ripening and immediately frozen at $-18{ }^{\circ} \mathrm{C}$. Analyses were performed within one week.

\subsection{Chemical analysis}

Dry matter, fat and protein determinations in sample cheeses were performed according to "Official Methods of Cheese Analysis" [26]. 


\subsection{Preparation of fatty acid methyl esters}

The fatty acid methyl esters were prepared by trans-esterification with potassium hydroxide according to ISO 5509:2000E [16].

Ten grams of cheese were homogenized, then an aliquot $(0.15 \mathrm{~g})$ was collected in a screw-capped test tube and sodium sulfate anhydrous $(1 \mathrm{~g})$, isooctane $(4 \mathrm{~mL})$ and methanolic potassium hydroxide solution $\left(300 \mu \mathrm{L} ; 2 \mathrm{~mol} \cdot \mathrm{L}^{-1}\right)$ were added. The test tube was closed and shaken vigorously for about $1 \mathrm{~min}$. After adding $1.5 \mathrm{~g}$ of sodium hydrogen sulfate monohydrate the tube was shaken again for $30 \mathrm{~s}$ to neutralize the excess of potassium hydroxide. The organic upper layer containing methyl esters was then transferred into a vial and immediately analyzed.

\subsection{Gas chromatographic analysis}

Fatty acid methyl esters were analyzed on a Varian gas chromatograph (Model 3400; Varian Assoc. Inc., Walnut Creek, CA, USA) using a DB-WAX capillary column $(30 \mathrm{~m}$ length, $0.25 \mathrm{~mm}$ internal diameter, $0.25 \mu \mathrm{m}$ phase thickness; J\&W Scientific Inc., Folsom, CA, USA), a splitsplitless injector and a flame ionization detector. The injected volume was $2 \mu \mathrm{L}$. The temperature program and operating conditions were as follow: injector and detector temperature $250{ }^{\circ} \mathrm{C}$; carrier gas helium at $1 \mathrm{~mL} \cdot \mathrm{min}^{-1}$; injection in splitless mode for $0.30 \mathrm{~min}$ and then split 1:60; the column was maintained at $35^{\circ} \mathrm{C}$ for 5 min then ramped at $2{ }^{\circ} \mathrm{C} \cdot \mathrm{min}^{-1}$ to $220^{\circ} \mathrm{C}$ and finally $5 \mathrm{~min}$ at $220^{\circ} \mathrm{C}$. Each sample was analyzed twice.

Data integration was performed with the EZCHROM $^{\text {TM }}$ data system (Scientific Software Inc., San Ramon, CA, USA).

Fatty acid methyl esters were identified by comparing their retention times with those of the reference standard (FAME mix $\mathrm{C}_{8}-\mathrm{C}_{24}$, Supelco Park, Bellefonte, PA, USA) and by a Shimadzu GC-17A gas
Table I. Major component concentrations of summer cheeses produced from mountain farms (24 samples) and winter cheeses produced from valley farms (42 samples).

\begin{tabular}{lcccc}
\hline & \multicolumn{2}{c}{$\begin{array}{c}\text { Winter } \\
\text { cheeses }\end{array}$} & \multicolumn{2}{c}{$\begin{array}{c}\text { Summer } \\
\text { cheeses }\end{array}$} \\
\hline x & $\sigma$ & $\mathrm{x}$ & $\sigma$ \\
\hline Dry matter $(\%)$ & 52.92 & 4.75 & 55.39 & 2.54 \\
Fat $(\% \mathrm{dm})$ & 19.53 & 5.71 & 27.89 & 3.49 \\
Protein $(\% \mathrm{dm})$ & 28.45 & 2.53 & 23.96 & 1.98 \\
\hline
\end{tabular}

$\mathrm{x}$ : mean value; $\sigma$ : standard deviation; dm: dry matter.

chromatograph coupled with a Shimadzu QP-5000 quadrupole mass spectrometer (Shimadzu, Tokyo, Japan) operating under the same chromatographic conditions. Mass spectra were recorded in electron impact mode at ionization voltage of $70 \mathrm{eV}$ in the 29-350 amu mass range. The ion source and interface were maintained at $220^{\circ} \mathrm{C}$. Compound identification was carried out by NIST 12 and NIST 62 mass spectral database.

\subsection{Statistical analyses}

Differences between $\mathrm{S}$ and $\mathrm{W}$ cheeses were investigated using analysis of variance (Statistica ver. 6.0; StatSoft Inc., Tulsa, OK, USA).

\section{RESULTS AND DISCUSSION}

Dry matter, fat and protein concentrations for $\mathrm{S}$ and $\mathrm{W}$ cheeses are reported in Table I. The difference for fat content is due to the different milk used in cheesemaking. Summer cheeses are produced with whole milk while winter cheeses are produced with partially skimmed milk.

In Table II the composition in FAMEs with 4 to 20 carbon atoms of $\mathrm{S}$ and $\mathrm{W}$ cheeses is reported.

Due to different diet compositions, short- $\left(\mathrm{C}_{4}, \mathrm{C}_{6}, \mathrm{C}_{8}\right)$ and medium-chain $\left(\mathrm{C}_{10}, \mathrm{C}_{12}, \mathrm{C}_{14}\right.$ and $\left.\mathrm{C}_{16}\right)$ saturated fatty 
Table II. FAMEs composition (C4 to C20) of summer (24 samples) and winter (42 samples) cheeses and significance value of analysis of variance $(P)$.

\begin{tabular}{|c|c|c|c|c|c|}
\hline & \multicolumn{2}{|c|}{ Winter cheeses } & \multicolumn{2}{|c|}{ Summer cheeses } & \multirow[b]{2}{*}{$P$} \\
\hline & $\mathrm{x}$ & $\sigma$ & $\mathrm{x}$ & $\sigma$ & \\
\hline $\mathrm{C}_{4: 0}$ & 3.51 & 0.37 & 3.11 & 0.22 & $<0.01$ \\
\hline$C_{6: 0}$ & 2.34 & 0.21 & 1.73 & 0.19 & $<0.01$ \\
\hline $\mathrm{C}_{8: 0}$ & 1.47 & 0.18 & 0.99 & 0.19 & $<0.01$ \\
\hline$\Sigma\left(\mathrm{C}_{4: 0}+\mathrm{C}_{6: 0}+\mathrm{C}_{8: 0}\right)$ & 7.32 & 0.67 & 5.84 & 0.54 & $<0.01$ \\
\hline $\mathrm{C}_{10: 0}$ & 3.01 & 0.47 & 1.92 & 0.44 & $<0.01$ \\
\hline $\mathrm{C}_{10: 1}$ & 0.37 & 0.10 & 0.23 & 0.05 & $<0.01$ \\
\hline $\mathrm{C}_{12: 0}$ & 3.25 & 0.85 & 2.07 & 0.39 & $<0.01$ \\
\hline $\mathrm{C}_{13: 0}$ & 0.11 & 0.04 & 0.12 & 0.05 & 0.555 \\
\hline $\mathrm{C}_{14: 0}$ & 11.92 & 0.85 & 8.32 & 0.82 & $<0.01$ \\
\hline $\mathrm{C}_{14: 0 \text { branched }}$ & 0.20 & 0.07 & 0.22 & 0.04 & 0.353 \\
\hline $\mathrm{C}_{14: 1}$ & 1.04 & 0.14 & 0.67 & 0.11 & $<0.01$ \\
\hline $\mathrm{C}_{15: 0}$ & 1.24 & 0.14 & 1.48 & 0.23 & $<0.01$ \\
\hline $\mathrm{C}_{15: 0 \text { branched }}$ & 1.03 & 0.15 & 1.19 & 0.11 & $<0.01$ \\
\hline$C_{16: 0}$ & 30.74 & 1.89 & 24.26 & 1.00 & $<0.01$ \\
\hline$C_{16: 0 \text { branched }}$ & 0.41 & 0.08 & 0.38 & 0.08 & 0.112 \\
\hline $\mathrm{C}_{16: 1}$ & 1.48 & 0.14 & 1.65 & 0.19 & $<0.01$ \\
\hline$\Sigma\left(\mathrm{C}_{10: 0}+\mathrm{C}_{12: 0}+\mathrm{C}_{14: 0}+\mathrm{C}_{16: 0}\right)$ & 48.93 & 3.37 & 36.57 & 2.14 & $<0.01$ \\
\hline $\mathrm{C}_{17: 0}$ & 0.74 & 0.20 & 0.93 & 0.13 & $<0.01$ \\
\hline$\Sigma\left(\mathrm{C}_{17: 0 \text { branched }}\right)$ & 1.22 & 0.15 & 1.30 & 0.26 & 0.101 \\
\hline $\mathrm{C}_{17: 1}$ & 0.34 & 0.09 & 0.41 & 0.12 & $<0.01$ \\
\hline $\mathrm{C}_{18: 0}$ & 10.17 & 0.95 & 12.72 & 1.06 & $<0.01$ \\
\hline $\mathrm{C}_{18: 1}$ & 21.48 & 1.74 & 29.37 & 1.75 & $<0.01$ \\
\hline cis- 9, trans $-11-\mathrm{C}_{18: 2}$ & 0.89 & 0.16 & 2.23 & 0.42 & $<0.01$ \\
\hline$\Sigma\left(\mathrm{C}_{18: 2}\right)^{*}$ & 2.48 & 0.55 & 2.95 & 0.48 & $<0.01$ \\
\hline $\mathrm{C}_{18: 3}$ & 0.75 & 0.15 & 1.30 & 0.25 & $<0.01$ \\
\hline$\Sigma\left(\mathrm{C}_{18: 0}+\mathrm{C}_{18: 1}+\mathrm{c}-9, \mathrm{t}-11-\mathrm{C}_{18: 2}+\Sigma \mathrm{C}_{18: 2}+\mathrm{C}_{18: 3}\right)$ & 34.89 & 2.67 & 46.33 & 2.36 & $<0.01$ \\
\hline$\Sigma\left(\mathrm{C}_{18: 1}+\mathrm{c}-9, \mathrm{t}-11-\mathrm{C}_{18: 2}+\Sigma \mathrm{C}_{18: 2}+\mathrm{C}_{18: 3}\right)$ & 24.71 & 1.90 & 33.62 & 1.71 & $<0.01$ \\
\hline $\mathrm{C}_{20: 0}$ & 0.15 & 0.06 & 0.28 & 0.10 & $<0.01$ \\
\hline $\mathrm{C}_{20: 1}$ & 0.14 & 0.06 & 0.19 & 0.06 & $<0.01$ \\
\hline$\Sigma$ saturated fatty acids & 71.51 & 3.33 & 61.02 & 1.75 & $<0.01$ \\
\hline$\Sigma$ unsaturated fatty acids & 28.08 & 1.92 & 39.00 & 1.66 & $<0.01$ \\
\hline $\begin{array}{l}\mathrm{C}_{16: 0} /\left(\mathrm{C}_{18: 0}+\mathrm{C}_{18: 1}+\mathrm{c}-9, \mathrm{t}-11-\mathrm{C}_{18: 2}\right. \\
\left.+\Sigma \mathrm{C}_{18: 2}+\mathrm{C}_{18: 3}\right)\end{array}$ & 0.89 & 0.10 & 0.53 & 0.05 & $<0.01$ \\
\hline $\mathrm{C}_{16: 0} /\left(\mathrm{C}_{18: 1}+\mathrm{c}-9, \mathrm{t}-11-\mathrm{C}_{18: 2}+\Sigma \mathrm{C}_{18: 2}+\mathrm{C}_{18: 3}\right)$ & 1.25 & 0.15 & 0.72 & 0.06 & $<0.01$ \\
\hline
\end{tabular}

The results are shown for each FAME as a percentage of total FAMEs. $x$ : mean value; $\sigma$ : standard deviation; *: sum of all conjugated geometric and positional isomers of linoleic acid except for cis-9, trans-11- $\mathrm{C}_{18: 2}$ isomer. 
acids were significantly more abundant in $\mathrm{W}$ cheeses whereas stearic $\left(\mathrm{C}_{18: 0}\right)$ and arachidic $\left(\mathrm{C}_{20: 0}\right)$ acids were greater in the $\mathrm{S}$ products, confirming the results of other authors [2, 3, 6, 13]. Among monounsaturated short- and medium-chain fatty acids, $\mathrm{C}_{10: 1}$ and $\mathrm{C}_{14: 1}$ were more abundant in $\mathrm{W}$ products while $\mathrm{C}_{16: 1}$ was more abundant in $\mathrm{S}$ cheeses, as already shown by Collomb et al. [6].

Transition from the hay/concentrate diet to the grazing diet was also followed by a great increase in the proportion of saturated, mono- and poly-unsaturated long-chain fatty acids $\left(\mathrm{C}_{18: 0}, \mathrm{C}_{18: 1}, \mathrm{C}_{18: 2}\right.$, $\mathrm{C}_{18: 3}$ ).

Very important for its nutritional effect is the increment in the $\mathrm{S}$ cheeses of conjugated linoleic acids, also known as CLA, that have been recently recognized as anticarcinogenics. In Table II the percentage of the most important isomer, the cis-9, trans-11 linoleic acid or rumenic acid and the sum of the other five geometric and positioned isomers are reported separately for these compounds.

Rumenic acid is reported separately because it is considered to be the most important CLA in terms of anticarcinogenic activity. In fact, it is the only isomer incorporated into the phospholipid fraction of tissues, it modulates the activity of cytochrome $\mathrm{P} 450$, reduces the induction of ornithine decarboxylase and protein kinase $\mathrm{C}$, known as tumour production indicators, and probably inhibits protein and nucleotide biosynthesis [28].

CLA are the intermediate stage of full biohydrogenation of linoleic acid to stearic acid [21, 22, 29], so their higher amount in $\mathrm{S}$ cheeses can be linked to the higher amount of $\mathrm{C}_{18: 1}$ and $\mathrm{C}_{18: 0}$ in these cheeses.

The high proportion of $\mathrm{c}-9, \mathrm{t}-11-\mathrm{C}_{18: 2}$ found in the $\mathrm{S}$ cheeses can be due to pasturing, as reported by other authors [12, $23,25,32]$ but also to the milkcontaminating microflora activity $[19,30]$ and the prolonged cooking of the curd (45-
$48 \mathrm{~min}$ at $40-45{ }^{\circ} \mathrm{C}$ in the summer production; $15-20 \mathrm{~min}$ at $37-40{ }^{\circ} \mathrm{C}$ in the winter production).

As reported by Lin et al. [24], the agitation of cheese curd during cooking facilitates CLA formation by incorporating air, enhancing the initiation of lipid oxidation and the production of linoleic radicals. Moreover, the interaction between proteins and fat globules increases and enables proteins to donate hydrogen to convert linoleic acid radicals to CLA.

The great increase in the $S$ cheeses of saturated, mono- and poly-unsaturated long-chain fatty acids $\left(\mathrm{C}_{18: 0}, \mathrm{C}_{18: 1}, \mathrm{C}_{18: 2}\right.$, $\left.\mathrm{C}_{18: 3}\right)$ leads to a reduction in $\mathrm{C}_{16: 0} /\left(\mathrm{C}_{18: 1}+\right.$ $\left.\mathrm{C}_{18: 2}+\mathrm{C}_{18: 3}\right)$ (1.20 for $\mathrm{W}$ cheeses; 0.67 for $\mathrm{S}$ cheeses $)$ and $\mathrm{C}_{16: 0} /\left(\mathrm{C}_{18: 0}+\mathrm{C}_{18: 1}+\mathrm{C}_{18: 2}\right.$ $\left.+\mathrm{C}_{18: 3}\right) \quad$ (0.86 for $\mathrm{W}$ cheeses; 0.50 for $\mathrm{S}$ cheeses) ratios, confirming the major influence of pasturing and particularly of mountain vegetation on milk fat composition [6, 31, 33, 35].

Compared with $\mathrm{W}$ cheeses, in the $\mathrm{S}$ cheeses there is also an increase in n-3 fatty acids and a decrease in the $n-6 / n-3$ ratio due to cows grazing in mountain pastures, with a very important nutritional effect since omega-3 polyunsaturated fatty acids are recognized as playing an essential role in human health and are particularly important for the proper functioning of the brain, heart and the retina of the eye [17].

\section{CONCLUSION}

This preliminary work has confirmed that, for "Ossolano" cheese, different feeding can significantly influence the cheese fat composition. Saturated shortand medium-chain fatty acids were thus more abundant in winter cheeses produced with the milk of cows fed on hay and concentrate. On the contrary, saturated, mono- and poly-unsaturated long-chain fatty acids were more abundant in summer cheeses produced with the milk of cows fed in mountain pastures. Very important 
for its nutritional effect is the increment in CLA and n-3 fatty acids and the decrease in the $n-6 / n-3$ ratio in these latter cheeses.

These differences in such factors of good quality and "typicality", along with other parameters such as terpenes, sesquiterpenes and aromatic polycyclic hydrocarbons could be used to indicate the mountain origin of the cheese with the prospect of an application for "Protected Denomination of Origin" (PDO).

\section{ACKNOWLEDGEMENT}

This research was supported by the Regione Piemonte - Assessorato Agricoltura - Project Interreg II "Caratterizzazione del formaggio Nostrano Ossolano" - Italy.

\section{REFERENCES}

[1] Banni S., Murru E., Angioni E., Carta G., Melis M.P., Conjugated linoleic acid isomers (CLA): good for everything?, Sci. Aliments 22 (2002) 371-380.

[2] Brun Bellut J., Laurent F., Vignon B., Effetti della alimentazione sulla composizione del latte, Latte 10 (1985) 314-326.

[3] Bugaud C., Buchin S., Coulon J.B., Hauwuy A., Dupont D., Influence of the nature of alpine pastures on plasmin activity, fatty acid and volatile compound composition of milk, Lait 81 (2001) 401-414.

[4] Bugaud C., Buchin S., Noël Y., Tessier L., Pochet S., Martin B., Chamba J.F., Relationships between Abondance cheese texture, its composition and that of milk produced by cows grazing different types of pastures, Lait 81 (2001) 593-607.

[5] Chilliard Y., Ferlay A., Mansbridge R.M., Doreau M., Agabriel J., Givens I., Ruminant milk fat plasticity: nutritional control of saturated, polyunsaturated, trans and conjugated fatty acids, Ann. Zootech. 49 (2000) 181-205.

[6] Collomb M., Bütikofer U., Spahni M., Jeangros B., Bosset J.O., Composition en acides gras et en glycérides de la matière grasse du lait de vache en zone de montagne et de plaine, Sci. Aliments 19 (1999) 97-110.

[7] Colombari G., Zapparoli G.A., Influence on the forage preservation system on acid composition of milk fat, Sci. Tec. Latt. Casearia 40 (1989) 299-310.

[8] Dhiman T.R., Anand G.R., Satter L.D., Pariza M.W., Conjugated linoleic acid content of milk from cows fed different diets, J. Dairy Sci. 82 (1999) 2146-2156.

[9] Fellin A., Barcarolo R., Tutta C., Tapparo F., Tapparo M., Experiments of fat addition in cows feeding and changes in milk fat composition, Sci. Tec. Latt. Casearia 40 (1989) 288-298.

[10] Gerson T., Shortland F.B., Wilson G.F., Reid C.W.S., Origin of glyceride fatty acids in cow milk fat, J. Dairy Sci. 51 (1968) 356-361.

[11] Grummer R.R., Effect of feed on the composition of milk fat, J. Dairy Sci. 74 (1991) 3244-3257.

[12] Ha Y.L., Grimm N.K., Pariza M.W., Newly recognized anticarcinogenic fatty acids: identification and quantification in natural and processed cheeses, J. Agric. Food Chem. 37 (1989) 75-81.

[13] Henninger M., Ulberth F., Trans fatty acid content of bovine milk fat, Milchwissenschaft 49 (1994) 555-558.

[14] Hill M.J., Dietary fat and human cancer (A review), Anticancer Res. 7 (1987) 281-292.

[15] Innocente N., Praturlon D., Corradini C., Fatty acid profile of cheese produced with milk from cows grazing on mountain pastures, Ital. J. Food Sci. 14 (2002) 217-224.

[16] ISO, International standard. Animal and vegetable fats and oils. Preparation of methyl esters of fatty acids. ISO 5509:2000(E), International Organisation for Standardisation, Geneve, Switzerland, 2000.

[17] Jahangiri A., Leifert W.R., McMurchie E.J., Omega-3 polyunsaturated fatty acids: recent aspects in relation to health benefits, Food Australia 54 (2002) 74-77.

[18] Jenkins T.C., Lipid metabolism in the rumen, J. Dairy Sci. 76 (1993) 3851-3863.

[19] Jiang J., Bjoerck L., Fonden R., Emanuelson M., Occurrence of conjugated cis- 9 , trans11-octadecadienoic acid in bovine milk: effects of feed and dietary regimen, J. Dairy Sci. 79 (1996) 438-445.

[20] Kelly M.L., Kolver E.S., Bauman D.E., Amburgh M.E., Muller L.D., Effect of intake of pasture on concentrations of conjugated linoleic acid in milk of lactating cows, J. Dairy Sci. 81 (1998) 1630-1636.

[21] Kepler C.R., Tove S.B., Biohydrogenation of unsaturated fatty acids, J. Biol. Chem. 242 (1967) 5686-5692. 
[22] Kepler C.R., Tucker W.P., Tove S.B., Biohydrogenation of unsaturated fatty acids. V. Stereospecificity of proton addition and mechanism of action of linoleic acid $\Delta^{12}$-cis, $\Delta^{11}$-trans-isomerase from Butyrivibrio fibrisolvens, J. Biol. Chem. 246 (1971) 2765-2771.

[23] Lin H., Boylston T.D., Chang M.J., Luedecke L.O., Shultz T.D., Survey of the conjugated linoleic acid contents of dairy products, J. Dairy Sci. 78 (1995) 2358-2365.

[24] Lin H., Boylston T.D., Luedecke L.O., Shultz T.D., Conjugated linoleic acid content of Cheddar-type cheeses as affected by processing, J. Food Sci. 64 (1999) 874-878.

[25] Martin A., Nutritional recommendations for the French population. The "Apports Nutritionnels Conseillés" (ANCs), Sci. Aliments 21 (2001) 309-460.

[26] Official Methods of Cheese Analysis. D.M 21.04.1986. Supplemento Ordinario Gazzetta Ufficiale n. 299 del 2.10.1986.

[27] Palmquist D.L., Jenkins T.C., Fat in lactation rations: Review, J. Dairy Sci. 63 (1980) 1-14.

[28] Parodi P.W., Conjugated linoleic acid: an anticarcinogenic fatty acid present in milk fat, Aust. J. Dairy Technol. 49 (1994) 93-97.

[29] Polan C.E., McNeill J.J., Tove S.B., Biohydrogenation of unsaturated fatty acids by rumen bacteria, J. Bacteriol. 88 (1964) 1056-1064.

[30] Prandini A., Geromin D., Conti F., Masoero F., Piva A., Piva G., Survey on the level of conjugated linoleic acid in dairy products, Ital. J. Food Sci. 13 (2001) 243-253.

[31] Precht D., Molkentin J., Effect of feeding on conjugated $c i s-\delta 9$, trans- $\delta 11$-octadecadienoic acid and other isomer of linoleic acid in bovine milk fats, Nahrung 41 (1997) 330-335.

[32] Werner S.A., Luedecke L.O., Shultz T.D. Determination of conjugated linoleic acid content and isomer distribution in three Cheddar-type cheeses: effects of cheese cultures, processing and aging, J. Agric. Food Chem. 40 (1992) 1817-1821.

[33] Wolff R.L., Bayard C.C., Fabien R.J., Evaluation of sequential methods for the determination of butterfat fatty acid composition with emphasis on trans-18:1 acids. Application to the study of seasonal variations in French butters, J. Am. Oil Chem. Soc. 72 (1995) 1471-1483.

[34] Wu Z., Ohajuruka O.A., Palmquist D.L., Ruminal synthesis. Biohydrogenation and digestibility of fatty acids by dairy cows, J. Dairy Sci. 74 (1991) 3025-3034.

[35] Zegarska Z., Paszczyk B., Borejszo Z., Trans fatty acids in milk fat, Polish J. Food Nutr. Sci. 5 (1996) 89-97. 